JESTT Vol. 1 No. 4 April 2014

\title{
ANALISIS KESESUAIAN SYARIAH PADA SISTEM OPERASI BISNIS MULTI LEVEL MARKETING (MLM) KK INDONESIA DENGAN FATWA DSN MUI NO: 75/DSN MUI/VII/2009
}

\author{
Ajeng Dwyanita \\ Mahasiswa Program Studi S-1 Ekonomi Islam - Fakultas Ekonomi dan Bisnis - Universitas \\ Airlangga \\ Irham Zaki \\ Departemen Ekonomi Syariah - Fakultas Ekonomi dan Bisnis - Universitas Airlangga \\ Email: irhamzaki0712@gmail.com
}

\begin{abstract}
Abstrak
The rise of business Multi Level Marketing (MLM) which is growing rapidly in Indonesia made many people interest to join. However, it is still debated by scholars regarding the business operations of Multi Level Marketing (MLM). In addition, MUI has publish DSN MUI Fatwa Number: 75/DSN MUI/VII/2009 about Direct Selling Based On Islamic Law.

This study aims to determine whether the business operations of the Multi Level Marketing (MLM) KK Indonesia is in conformity with the Shariah rules to follow 12 of the MUI fatwa or not.

This study used a qualitative analysis using interview guide. The data used in this study is that the data derived from primary data obtained from fieldwork and secondary data derived from the literature and the MUI Fatwa DSN. In this study using data derived from the management of Multi Level Marketing (MLM) PT . KK Indonesian branch of Surabaya, East Java and Indonesian Ulema Council (MUI) East Java.

The results of the study were operating Multi Level Marketing (MLM) KK Indonesia's procedures are in line with the Indonesian Ulama Council fatwa DSN Number: 75/DSN MUI/VII/2009.
\end{abstract}

Keywords : Sharia Multi Level Marketing, Business Operations, Fatwa DSN MUI

\section{PENDAHULUAN}

\section{A. Latar Belakang}

Beberapa tahun belakangan ini,

dunia bisnis di Indonesia mengalami perkembangan yang cukup pesat Perkembangan dunia bisnis yang pesat di Indonesia tersebut salah satunya dipengaruhi oleh faktor globalisasi. Perkembangan bisnis di Indonesia kini telah memasuki era globalisasi. Era globalisasi merupakan era di mana batas antar negara tidak lagi menjadi pemisah. Dengan kata lain tidak ada lagi penyekat yang memisahkan hubungan antar negara untuk saling berinteraksi dalam segala hal. Salah satunya adalah bisnis.
Hal utama yang signifikan dari keberadaan era globalisasi yang mulai masuk dalam dunia bisnis adalah bahwa pengusaha dituntut untuk selalu berkembang terus menerus. Hal tersebut menjadi logis karena konsekuensi nyata yang didapat apabila seorang pengusaha tidak mampu berkembang adalah tidak akan mampu survive pada dunia bisnis. Secara tidak langsung era globalisasi tersebut berpengaruh terhadap pengusaha untuk dituntut semakin berkembang pesat. Era globalisasi tersebut, dimulai dengan terjadinya perdagangan bebas Asean Free Trade Area (AFTA) pada tahun 2003. 
Selanjutnya, implikasi nyata dari adanya era globalisasi tersebut dilanjutkan dengan terjadinya perdagangan bebas Asia Pasific Economic Coorporation (APEC) pada tahun 2010 bagi negara-negara maju. Selain itu ketentuan dari dilaksanakannya APEC ini juga harus diikuti oleh negara maju paling lambat hingga tahun 2020 dan paling lambat 2020 bagi negaranegara berkembang.

Perkembangan bisnis ini juga menghadirkan banyak pemain - pemain baru dalam dunia bisnis. Banyak masyarakat yang dulunya bukan sebagai pengusaha beralih menjadi pengusaha yang memulai bisnis baru untuk menyemarakkan dunia bisnis di Indonesia. Berbagai macam sistem yang mereka kembangkan, mulai dari berdagang di kawasan pertokoan, berdagang secara online, dan masih banyak cara berdagang yang lainnya. Namun dari berbagai macam cara dan sistem bisnis yang ada tersebut, sistem berbisnis secara online menjadi sistem bisnis yang paling diminati di Indonesia saat ini.

Berdasarkan macam sistem bisnis yang saat ini dikembangkan dan dijalankan di Indonesia, yang sekarang makin marak dibahas adalah bisnis Multi Level marketing (MLM). Bisnis ini banyak dibahas karena menuai banyak kontra dalam segi halal haram yang ditinjau secara syariah. Selain itu, banyak dari umat muslim di Indonesia yang menjadi bagian dari bisnis syariah tersebut.
Dalam beberapa tahun terakhir, bisnis Multi Level Marketing (MLM) sedang diminati oleh banyak orang terlebih beberapa barang yang dapat diperjualbelikan melalui sistem ini tanpa dibatasi segmentasi tertentu. Beberapa contoh diantaranya adalah kosmetik, obat - obatan, dan hingga yang tak kalah mengejutkan adalah $\mathrm{mlm}$ haji. Namun, hal yang masih menjadi perdebatan oleh banyak pihak sehingga menjadi topik yang sering diperbincangkan adalah mengenai halal haramnya bisnis MLM ini.

\section{LANDASAN \\ TEORI \\ PENGEMBANGAN PROPOSISI}

DAN

Istilah bisnis, Menurut wikipedia.com adalah suatu organisasi yang menjual barang atau jasa kepada konsumen atau bisnis lainnya, untuk mendapatkan laba. Secara historis kata bisnis dari bahasa Inggris business, dari kata dasar busy yang berarti "sibuk" dalam konteks individu, komunitas, ataupun masyarakat. Dalam artian, sibuk mengerjakan aktivitas dan pekerjaan yang mendatangkan keuntungan.

Operasi bisnis adalah semua aktivitas untuk menyediakan produk (barang atau layanan) bisnis, untuk menjamin bisnis dapat memperoleh keuntungan (mencapai tujuan). (Eva hariyanti:2012) Sedangkan Multi Level Marketing (MLM) atau yang biasa disebut secara singkat dengan MLM merupakan suatu cara perniagaan alternatif yang berkaitan dengan pemasaran yang dilakukan melalui banyak level (tingkatan), yang 
bisa dikenal dengan itilah upline (tingkat atas) dan downline (tingkat bawah), orang akan disebut upline jika mempunyai downline. Pokok utama dari perniagaan Multi Level Marketing (MLM) ini digerakkan dengan jaringanini, sama ada yang bersifat vertikal atau horizontal taupun gabungan keduanya. (Santoso, 2006:28)

Dewan Syariah Nasional Majelis Ulama Indonesia (DSN MUI) telah mengeluarkan 12 poin dari fatwa mengenai pedoman penjualan langsung berjenjang syariah atau yang biasa disebut Multi Level Marketing (MLM) dengan nomor 75/DSN/MUI/VII/2009 pada tanggal 25 Juli 2009 di Jakarta. 12 poin tersebut adalah :

1. Adanya obyek transaksi riil yang diperjualbelikan berupa barang atau produk jasa;

2. Barang atau produk jasa yang diperdagangkan bukan sesuatu yang diharamkan dan atau yang dipergunakan untuk sesuatu yang haram;

3. Transaksi dalam perdagangan tersebut tidak mengandung unsur gharar, maysir, riba, dharar, dzulm, maksiat;

4. Tidak ada kenaikan harga/biaya yang berlebihan (excessive markup), sehingga merugikan konsumen karena tidak sepadan dengan kualitas/manfaat yang diperoleh;

5. Komisi yang diberikan oleh perusahaan kepada anggota baik besaran maupun bentuknya harus berdasarkan pada prestasi kerja nyata yang terkait langsung dengan volume atau nilai hasil penjualan barang atau produk jasa, dan harus menjadi pendapatan utama mitra usaha dalam PLBS;

6. Bonus yang diberikan oleh perusahaan kepada anggota (mitra usaha) harus jelas jumlahnya ketika dilakukan transaksi (akad) sesuai dengan target penjualan barang dan atau produk jasa yang ditetapkan oleh perusahaan;

7. Tidak boleh ada komisi atau bonus secara pasif yang diperoleh secara reguler tanpa melakukan pembinaan dan atau penjualan barang dan atau jasa;

8. Pemberian komisi atau bonus oleh perusahaan kepada anggota (mitra usaha) tidak menimbulkan ighra';

9. Tidak ada eksploitasi dan ketidakadilan dalam pembagian bonus antara anggota pertama dengan anggota berikutnya;

10. Sistem perekrutan keanggotaan, bentuk penghargaan dan acara seremonial yang dilakukan tidak mengandung unsur yang bertentangan dengan aqidah, syariah dan akhlak mulia, seperti syirik, kultus, maksiat dan lain-lain;

11. Setiap mitra usaha yang melakukan perekrutan keanggotaan berkewajiban melakukan pembinaan dan 
pengawasan kepada anggota yang direkrutnya tersebut;

12. Tidak melakukan kegiatan money game.

\section{METODE PENELITIAN}

Pendekatan yang digunakan dalam penelitian ini adalah pendekatan kualitatif. Menurut Sugiyono (2012 : 9), metode penelitian kualitatif adalah metode penelitian yang berlandaskan pada filsafat postpositivisme, digunakan peneliti untuk memeliti pada kondisi obyek yang alamiah, (sebagai lawannya adalah eksperimen) dimana peneliti adalah sebagai instrumen kunci, teknik pengumpulan data/kualitatif, dan hasil penelitian kualitatif lebih menekankan makna pada generalisasi. Metode kualitatif digunakan ketika permasalahan yang akan diteliti masih belum ditentukan secara pasti. Atau dapat dikatakan masih abu-abu.

Ruang lingkup penelitian ini adalah terbatas pada hukum bisnis Multi Level Marketing (MLM) dalam perspektif ekonomi Islam yang dicari melalui penganalisaan sistem operasional bisnis pada Multi Level Marketing (MLM) KK Indonesia.

Jenis data dalam penelitian ini adalah data primer sebagai data utama dan data sekunder sebagai data tambahan. Data primer dapat diperoleh secara langsung yaitu dengan cara menanyakan pertanyaan kepada seseorang yang menjadi informan dan mengumpulkan dokumentasi. Informan dalam penelitian ini adalah yang pertama adalah Crown
Star Director dari Multi Level Marketing (MLM) KK Indonesia yaitu Diah Puspitawati dan yang kedua adalah anggota komisi fatwa Majelis Ulama Indonesia (MUI) yaitu Prof. Dr. H. A. Faisol Haq, M.Ag. Sedangkan data sekunder adalah data yang berasal dari dokumen-dokumen perusahaan, buku-buku yang berkaitan dengan jual beli dan bisnis secara Islam, juga ditunjang dengan data-data yang dilakukan melalui browsing internet dan sumber - sumber lain yang relevan. Dalam penelitian ini, data penunjang adalah data-data relevan yang diperoleh dari Multi Level Marketing (MLM) KK Indonesia cabang Surabaya dan juga dokumentasi pada saat wawancara. Selain itu juga didapat dari penelitian-penelitian terdahulu mengenai Multi Level Marketing (MLM).

Sugiyono (2010:243) menjelaskan bahwa analisis data dalam penelitian kualitatif dilakukan pada saat pengumpulan data berlangsung dan setelah penelitian. Penelitian ini menggunakan teknik analisis lapangan model Miles and Hubernan. Tahap teknik analisis yang pertama adalah dengan menggunakan data reduksi. Dalam penelitian di lapangan, akan diperoleh data yang jumlahnya banyak. Oleh karena itu, data harus dipersempit untuk memudahkan peneliti dalam menemukan jawaban penelitian atas masalahnya. Tahapan teknik analisis data yang kedua adalah dengan menggunakan data display. Selanjutnya, tahapan teknik analisis data yang ketiga adalah dengan menggunakan conclusion drawing atau kesimpulan dan verifikasi. 
Teknik validasi yang digunakan adalah uji kredibilitas dengan menggunakan cara bahan refrensi

\section{DESKRIPSI HASIL DAN PEMBAHASAN}

KK Indonesia didirikan di Jakarta pada 8 Januari 1999. Pada saat berdirinya kala itu, kondisi Indonesia tengah dilanda krisis moneter. Ratusan perusahaan mengalami kebangkrutan, tak terkecuali industriindustri Multi Level Marketing (MLM) yang berdiri jauh sebelum KK Indonesia. Ditambah lagi dengan banyaknya investor yang membatalkan investasinya, menjadikan perekonomian Indonesia semakin terpuruk. Namun, di sisi lain para founding fathers KK Indonesia justru memandang kekuatan di balik krisis yang telah melahirkan ratusan ribu pengangguran. Di saat perusahaan lain berbondong-bondong meninggalkan Indonesia, KK Indonesia justru datang memberi kesempatan baru bagi masyarakat untuk memperbaiki kehidupan ekonomi mereka. KK Indonesia berani menetapkan sebuah visi yang disebut "GO 1\%" yaitu untuk melatih sebanyak $1 \%$ dari populasi seluruh penduduk Indonesia menjadi wirausaha yang mandiri, berkarakter positif, dan sukses. Dengan kata lain, apabila visi tersebut terealisasi maka sebanyak kurang lebih 2,5 juta jiwa penduduk Indonesia sudah menyandang status baru yaitu sebagai wirausaha yang mandiri dan sukses. Visi tersebut merupakan bentuk implementasi dari prinsip dasar KK Indonesia yakni "Sehat, Kaya, Bahagia".
Adapun yang menjadi visi utama dari KK adalah wisma KK Indonesia, sekolah KK Indonesia, Perumahan KK Indonesia, Yayasan KK Indonesia, dan pabrik produk harian KK Indonesia. Sedangkan misi dari KK Indonesia adalah komitmen kepada distributor, konsumen, karyawan, network marketing, dan negara.

\section{A. Produk dan Harga}

Seperti hal-nya pada perusahaan Multi Level Marketing (MLM) lainnya yang memiliki produk untuk dipasarkan, KK Indonesia juga memiliki produk unggulan yang dipasarkan. Berdasarkan hasil wawancara dengan Crown Star Director Diah Puspitasari didapatkan hasil bahwa: "KK Indonesia sebagai perusahaan Multi Level Marketing memiliki sisi pembeda dibandingkan dengan perusahaan Multi Level Marketing. Adapun sisi pembeda itu yang pertama didapatkan melalui segmentasi atau jenis produk yang dijual. Apabila perusahaan Multi Level Marketing lainnya hanya berfokus pada satu segmentasi produk, KK Indonesia justru menjadi perusahaan Multi Level Marketing yang dapat dikategorikan multi segmentasi. Hal tersebut dapat dilihat melalui 5 jenis produk yang selama ini dijual oleh KK Indonesia."

Adapun kelima jenis produk yang dipasarkan oleh KK Indonesia, sebegaimana dikatakan oleh Crown Star Director Diah Puspitasari, yaitu kecantikan, kesehatan alami, kesehatan umum, makanan dan minuman kesehatan, serta perawatan diri dan rumah tangga.

\section{B. Perekrutan Member}


KK Indonesia membuka pintu lebar bagi siapa saja yang ingin bergabung baik hanya menjadi member maupun dan distributor dari MLM KK Indonesia. Berdasarkan ketentuan yang tertera dalam website maupun dalam katalog yang berisikan tata cara registrasi yang dikeluarkan oleh KK Indonesia, terdapat syarat yang harus dipenuhi oleh siapapun yang berkenan untuk menjadi anggota Multi Level Marketing Indonesia. Adapun yang menjadi syarat yaitu berusia minimal 17 tahun yang sudah mempunyai kartu identitas seperti KTP, SIM, atau paspor bagi warga negara asing. Sedangkan untuk pasangan suami istri, member KK berlaku sepasang dan tidak diperbolehkan suami istri membuat keaggotaan yang berbeda. Selain itu, seseorang yang sudah menjadi member, tidak boleh menjadi member lagi dibawah sponsor orang lain.

\section{Rencana Pemasaran dan Jenjang Karir}

Adapun nilai-nilai serta kemampuan manajemen tersebut dirumuskan dalam "8 Rencana Pemasaran" yang terdapat dalam Profil Perusahaan maupun dalam Kode Etik tetang Business Plan serta menjadi kelebihan atau strength point dari KK Indonesia, yaitu : Retailing Profit, Accumulative Perfomance Bonus,Leadership Development Bonus Dynamic Bonus, Motorbike Fund (MBF), Car House Education Fund (CHEF), Director Pool, Leadership Incentive Tour (LITO).

Dalam melakukan kinerja selama bergabung dengan Multi Level Marketing KK Indonesia, terdapat 6 (enam) tingkatan yang menjadi acuan para member dalam meraih jenjang karir pada perusahaan Multi Level Marketing KK Indonesia, yaitu : Star Manager, Ruby Star Manager, Pearl Star Manager, Emerald Star Director (ESD), Diamond Star Director (DSD), Crown Star Director (CSD).

\section{Pelatihan Member KK Indonesia}

Dalam operasional bisnisnya, KK Indonesia sebagai perusahaan tidak serta merta membiarkan para distributornya bekerja dalam mencari member tanpa memberikan bekal. MLM ini juga memberikan bimbingan kepada para distributor melalui seminar atau training yang dilakukan secara berkesinambungan. Hal tersebut sebagaimana juga ditegaskan oleh Crown Star Director Diah Puspitawati :

"Di KK Indonesia, pelatihan yang diberikan banyak sekali jenisnya, mulai dari seminar di dalam kota maupun di luar kota juga kegatan outbond. Tidak jarang juga kegiatan diisi dengan hal yang bersifat rohani. Itu untuk menunjukkan bahwa KK tidak hanya fokus untuk memberikan pelatihan secara jasmani, tetapi juga memberikan pelatihan secara rohani. Bahkan, saya sendiri sebagai seorang Crown Star Director dengan distributor yang menjadi binaan saya yang tersebar di berbagai kota, harus selalu membuat jadwal rutin setiap bulannya untuk memberikan pelatihan. Misal saja untuk minggu pertama bulan ini saya akan memberikan pelatihan di surabaya dan sekitarnya. Kemudian minggu depan saya memberikan pelatihan di Bali. Jadi 
pelatihan yang diberikan untuk distributor akan dilakukan secara berkesinambungan."

Pelatihan yang diberikan KK Indonesia dapat dibedakan menjadi 2 (dua) yaitu bersifat gratis dan berbayar. Namun jikalau berbayar pun, manfaat yang diperoleh dari pelatihan tersebut akan setara dengan biaya yang telah dikeluarkan. Dalam setiap pelatihan yang diberikan, KK Indonesia tak jarang memberikan seminar kit berupa penjelasan bahan seminar dan buku motivasi kepada setiap peserta. Selain itu, dengan mengikuti seminar member akan mendapatkan care reward yang dapat ditukarkan dengan produk tertentu sesuai kebutuhan.

\section{E. Money Game}

KK Indonesia sebagai perusahaan Multi Level Marketing yang telah terdftar dalam APLI atau Asosiasi Penjualan Langsung Indonesia. Dengan kata lain KK Indonesia merupakan salah satu perusahaan dengan sistem Multi Level Marketing yang tidak melakukan kegiatan money game dalam sistemnya karena salah satu syarat untuk menjadi member dari APLI, Multi Level Marketing tidak melakukan kegiatan money game.

Dalam melakukan analisis atau tinjauan syariah ini, penulis menggunakan 12 point seperti yang telah tercantum dalam fatwa tersebut. Adapun 12 point tersebut adalah

1. Adanya obyek transaksi riil yang diperjualbelikan berupa barang atau produk jasa.
Berdasarkan hasil wawancara dengan Crown Star Director Diah Puspitasari didapatkan hasil bahwa:

"KK Indonesia sebagai perusahaan Multi Level Marketing memiliki sisi pembeda dibandingkan dengan perusahaan Multi Level Marketing. Adapun sisi pembeda itu yang pertama didapatkan melalui segmentasi atau jenis produk yang dijual. Apabila perusahaan Multi Level Marketing lainnya hanya berfokus pada satu segmentasi produk, KK Indonesia justru menjadi perusahaan Multi Level Marketing yang dapat dikategorikan multi segmentasi. Hal tersebut dapat dilihat melalui 5 jenis produk yang selama ini dijual oleh KK Indonesia."

Menurut penulis, Poin pertama fatwa DSN MUI ini menjadi patokan bagi masyarakat untuk melihat apakah sebuah perusahaan yang mengklaim menggunakan sistem Multi Level Marketing (MLM) telah memenuhi sistem syariah atau tidak. Sebuah perusahaan yang menggunakan sistem Multi Level Marketing (MLM) haruslah menjual produk atau jasa secara nyata dengan kata lain dalam sebuah akad perjanjian jual beli disebutkan dengan jelas mengenai barang yang akan menjadi objek perjanjian. Adanya barang yang dijual juga merupakan salah satu rukun dari jual beli yang harus dipenuhi oleh kedua belah pihak yang terlibat dalam sebuah akad perjanjian. Pada penelitian yang dilakukan oleh peneliti dalam Multi Level Marketing (MLM) KK Indonesia, perusahaan menjual produk yang dibagi menjadi 5 (lima) 
kelompok seperti yang telah dijelaskan penulis pada pembahasan sebelumnya. Penjualan produk-produk tersebut merupakan sumber penghasilan utama dari KK Indonesia. Dengan demikian, syarat pertama yang terdapat pada fatwa Majelis Ulama Indonesia, telah terpenuhi oleh KK Indonesia dalam menjalankan bisnisnya dengan melakukan pemasaran terhadap produknya yang terbagi ke dalam 5 (lima) jenis.

2. Barang atau produk jasa yang diperdagangkan bukan sesuatu yang diharamkan dan atau yang dipergunakan untuk sesuatu yang haram.

Dari hasil penelitian telah dapat diketahui bahwa produk KK Indonesia bersifat multi segmen atau dengan kata lain terdiri dari beberapa jenis mulai dari produk kesehatan alami, kesehatan umum, kecantikan, makanan dan minuman dan lain-lain. Kesemua produk tersebut dipasarkan dengan merujuk pada visi KK Indonesia untuk mendukung tujuan dalam menyehatkan masyarakat. Oleh karena itu, bahan yang digunakan oleh KK Indonesia adalah bahan yang tidak menimbulkan efek samping yang bersifat menyakiti dan juga telah mendapatkan sertifikasi uji POM dan uji halal. Hal tersebut sebagaimana dikatakan oleh Crown Star Director Diah Puspitawati :

"KK Indonesia merupakan satu-satunya produsen Food Suplement yang diundang dalam acara yang diselenggarakan oleh Majelis Ulama Indonesia yaitu pada Bazaar Makanan Halal. Dalam hal ini produk yang dimaksud adalah
Supergreen Food. Tidak hanya itu, Supergreen Food ini juga telah ditunjuk secara resmi untuk menjadi sponsor utama pada acara Jakarta Marathon yang bertaraf Internasional."

Menurut Prof. Faisol Haq, tidak semua makanan memang ada label halalnya. Pada umumnya, yang mendapatkan perhatian khusus adalah produk makanan yang berbasis hewani. Karena dikhawatirkan produk makanan yang komposisinya mengandung hewani berasal dari lemak babi. Namun, jika berasal dari bahan nabati biasanya sudah halal tanpa perlu di sertifikasi lagi.

3. Transaksi dalam perdagangan tersebut tidak mengandung unsur gharar, maysir, riba, dharar, dzulm, maksiat.

Gharar yang dimaksudkan dalam fatwa ini adalah transaksi yang tidak jelas, misalnya pada harga, jenis, spesifikasinya, ukuran dan lain sebagainya. Pada penelitian, penulis menemukan brosurbrosur, x-banner, dan kemasan pada produk MLM KK Indonesia terdapat ukuran kemasan, kandungan, bahkan beberapa brosur ada yang menerangkan penelitian dari beberapa ahli dan manfaat yang diperoleh dari produk tersebut. Selain itu, KK Indonesia juga memberikan daftar harga sebagai acuan yang menerangkan ukuran atau takaran produk beserta harga. Menurut Prof. Faisol Haq bahwa:

"kalau sudah dijelaskan takaran dan jenisnya serta informasi lain berarti tidak gharar."

Menurut penulis, sebagaimana fakta yang telah didapat melalui hasil penelitian dan 
juga pendapat ahli, maka dapat disimpulkan bahwa produk KK Indonesia yang dijual tidaklah dapat dikatakan Gharar karena segala sesuatu yang disyaratkan dalam unsur Gharar tidaklah terpenuhi.Terlebih dalam setiap produk yang dijual KK Indonesia telah berupaya untuk memberikan informasi yang berguna untuk para konsumennya.

Larangan maysir yang terdapat dalam Fatwa DSN MUI tersebut mengacu pada Al-Quran surat Al Maidah ayat 1 dan 2. Maysir adalah sebuah bentuk perjudian atau segala sesuatu yang mengandung unsur peruntungan dan taruhan. Jadi dalam maysir, ada pihak yang diuntungkan dan ada pihak yang dirugikan. Bagian downline yang diberikan kepada upline sebagai bentuk upah secara tidak langsung atas usaha yang diberikan upline dalam melakukan pembinaan kepada downlinenya. Menurut Prof. Faisol Haq bahwa:

"hal tersebut wajar karena jasa ilmu tersebut yang seharusnya tidak ternilai harganya. Dan pahala ilmu yang bermanfaat akan tetap mengalir walaupun orang tersebut sudah meninggal."

Penulis berkesimpulan bahwa pengaturan pemberian bonus atau komisi telah dipaparkan dalam marketing plan yang dijelaskan oleh KK Indonesia. Sehingga tidak terdapat unsur masyir seperti yang disyaratkan dalam fatwa Majelis Ulama Indonesia. Hal tersebut dapat terlihat bahwa setiap orang yang ingin menjadi member atau distributor telah dijelaskan oleh pihak KK Indonesia mengenai apa yang menjadi hak dan kewajibannya. Hal tersebut bahkan telah terlampir dalam kode etik KK Indonesia.

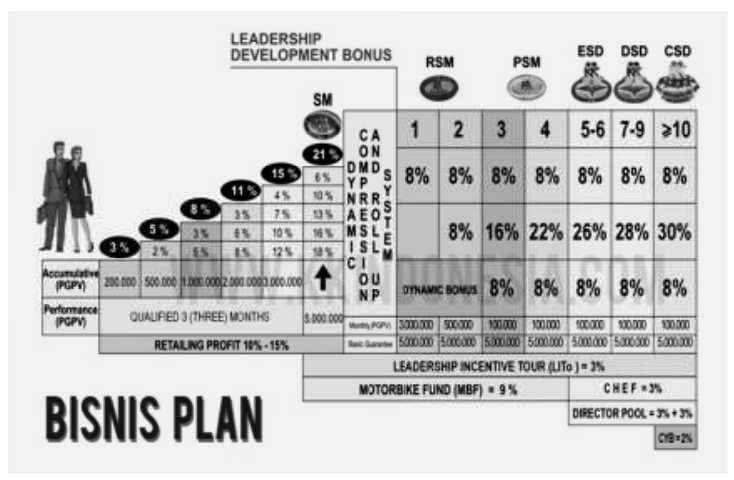

\section{Marketing plan Multi Level Marketing (MLM) KK Indonesia}

Sumber :

http://kkindonesia.com/pilar3_2.html Berkaitan dengan unsur riba yang selama ini dipertanyakan khususnya pada praktik Multi Level Marketing, Crown Star Director Diah Puspitawati memberikan gambaran : "Andaikan distributor A mempunyai sebuah grup yang beranggotakan $B$, C,dan D. A sebagai leader memberikan pelatihan kepada B, C, D secara berkesinambungan hingga akhirnya $B, C$, dan D berhasil mencapai target kerja. Dari kinerja yang dilakukan tersebut tentu akan melahirkan bonus. Kemudian bonus total dari grup tersebut akan dibagikan dahulu kepada B, C, dan D sesuai usaha yang diperoleh dengan patokan marketing plan, setelah itu sisanya baru diberikan kepada A."

Larangan unsur riba mengacu pada Al Quran Surat Al-Baqarah ayat 275. Riba adalah pengambilan tambahan harta atau modal pokok secara bathil. Menurut Prof. Faisol Haq : 
"Walaupun hanya melakukan

pembinaan, namun hal tersebut usaha

dan dasarnya pada ayat 26 Q.S. 10.

Cuma di lapangan sering ada

penyimpangan yang harus kita luruskan

mengenai sistem tersebut."

Menurut penulis, aturan peberian bonus yang terdapat dalam marketing plan KK Indonesia berdasarkan hasil yang dilakukan oleh distributor tersebut tidak semata-mata datang dengan sendirinya tanpa didukung oleh pembelian produk dan perekrutan serta pembinaan member. Distributor mencari dan membina orang-orang yang direkrut sehingga wajar jika distributor tersebut mendapatkan hasil yang sesuai dengan jerih payahnya. Sama dengan orang yang bekerja disuatu tempat, orang tersebut akan dibayar sesuai dengan jerih payahnya dalam mengerjakan sesuatu

Selain itu, bonus yang diterima oleh distributor telah dikurangi dan dibagi secara merata kepada distributordistributor yang disponsorinya. Sehingga bonus yang diberikan pada leader merupakan bentuk upah yang diberikan karena telah membina dan memberikan ilmu yang telah diberikan kepada downlinenya sehingga hal tersebut wajar dan tidak dhalim. Oleh karena itu, penulis menyimpulkan bahwa pada Multi Level Marketing (MLM) KK Indonesia tidak ditemukan adanya unsur riba dalam transaksi bonusnya. Sehingga memenuhi salah satu poin pada ketentuan nomor 3.

Dalam hal pendaftaran member, KK Indonesia memberikan 2 paket penawaran disertai dengan penjelasan baik untuk member maupun untuk distributor. Dharar sebagaimana dimaksud dalam Fatwa MUI yang bersangkutan merupakan unsur yang membahayakan. Dharar adalah ketakutan pada bahaya yang mengancam sesorang. Unsur dharar pada MLM adalah member akan terkena sanksi apabila tidak melakukan perekrutan orang.

Menurut Prof. Faisol Haq :

"Orang dalam melakukan jual beli tidak boleh ada persyaratannya. Harus samasama rela sama rela."

Menurut penulis, apa yang telah dicantumkan oleh KK Indonesia dalam kode etik berkaitan dengan dharar ini telah benar. Tidak ditemukan adanya paksaan dari KK Indonesia kepada para anggotanya untuk selalu melakukan perekrutan anggota baru.

Dzulm sebagaimana dimaksud dalam fatwa MUI adalah melanggar hak orang lain. Menurut Prof. Faisol Haq :

"Jawabannya hampir sama dengan poin nomor 5. Pada pertanyaan nomor 6 mengandung intisari dari Q.S An-nisa ayat 29."

Menurut penulis, pelanggaran dzulm tidak terjadi pada KK Indonesia, karena setiap distributor pada setiap bulannya akan diberikan bonus sesuai dengan usahanya pada bulan tersebut. Selain itu bonus tidak didasarkan pada target yang harus dicapai member pada bulan tersebut. Pada penelitian, Multi Level Marketing (MLM) KK Indonesia menetapkan bahwa bonus yang didapatkan oleh setiap 
konsumen tiap bulannya dihitung pada setiap tanggal 30 (tiga puluh) bulan berjalan. Setelah itu, bonus akan dibayarkan pada tanggal 15 (lima belas) bulan berikutnya. Bonus tersebut akan langsung dibayarkan dengan cara transfer sesuai ke rekening masing-masing distributor yang telah didaftarkan. Namun, ada pengecualian bonus yang hanya bisa diambil di kantor cabang terdekat jika ada peraturan tertulis yang dikeluarkan. Hal tersebut sesuai dengan kode etik perusahaan Bab IX tentang pembayaran bonus.

MLM KK Indonesia telah menetapkan bahwa seorang distributor yang akan melakukan perekrutan orang sebagai member baru atau sponsporing tidak boleh didasarkan ataas paksaan atau ancaman. Hal tersebut sebagaimana terdapat pada Bab II nomor 34 tentang hak, kewajiban, dan tanggung jawab seorang distributor. Sehingga tidak terdapat unsur maksiat.

4. Tidak ada kenaikan harga/biaya yang berlebihan (excessive mark up), sehingga merugikan konsumen karena tidak sepadan dengan kualitas/manfaat yang diperoleh.

Menurut Ulama MUl, Prof. Faisol Haq, beliau kurang setuju dengan adanya fatwa poin ke-4 (empat). Beliau merasa bahwa fatwa tersebut mengebiri produsen karena perusahaan mempunyai ketetapan masing-masing dalam menentukan harga sesuai dengan bahan yang mereka gunakan beserta kelebihan dari produk-produk tersebut.
Sehingga penulis menarik kesimpulan bahwa KK Indonesia masih melakukan exsessive mark up. Karena dengan pembandingan produk sejenis, harga produk Indonesia memang relatof lebih mahal dengan produk sejenis yang kandungannya sama. Walaupun tidak semua produknya, namun suatu MLM dikatakan memenuhi syarat jika semua produknya tidak melakukan excessive mark up. Walaupun sebagian sudah tidak jauh berbeda, namun hal tersebut harusnya diterapkan secara sama pada produk lainnya. Tidak bbisa dikatakan hanya sebagian yang tidak mark up lalu produk lainnya dikatakan juga tidak mark up.

5-9. Ketentuan yang terdapat dalam fatwa Majelis Ulama Indonesia khususnya pada poin ke-5 (lima) hingga poin ke 9 ( sembilan) pada intinya memiliki maksud yang sama bahwa dalam perhitungan dan pemberian bonus maupun bentuk penghargaan yang dapat diakumulasikan ke dalam pendapatan haruslah jelas seperti yang tertuang dalam akad dan didasarkan pada bentuk kerja nyata atas penjualan produk atau dengan kata lain tidak diperbolehkan perhitungan bonus yang didapat tanpa melakukan suatu usaha tertentu yang berkaitan dengan penjualan produk. Selain itu, juga tidak diperbolehkan karena adanya pemeberian bonus tersebut hingga menimbulkan ketidakadilan untuk sesama anggota.

MLM KK Indonesia menetapkan perhitungan pendapatan yang dihasilkan 
berdasarkan kerja masing-masing individu dan kelompoknya jika bergabung untuk menjadi distributor. Marketing plan yang telah ditetapkan menjadi acuan dalam perhitungan bonus yang akan diberikan oleh KK Indonesia kepada member yang telah mencapai target tertentu berdasarkan usaha atau performanya, bukan berdasarkan iming-iming dari pihak perusahaan atau distributor yang menjadi pihak sponsorshipnya yang berlebihan.

Tidak ada jaminan yang diberikan KK Indonesia apabila seorang distributor telah terlebih dahulu menjadi sponsor akan memiliki penghasilan yang leih besar. Distributor yang disponsorinya bisa jadi mendapat penghasilan yang lebih besar dikarenakan usahanya yang semakin banyak dalam penjualan produk dan perekrutan member baru. Hal tersebut sesuai dengan kode etik perusahaan KK Indonesia Bab II nomor 6 mengenai hak, kewajiban, dan tanggung jawab seorang distributor.

10. Sistem perekrutan keanggotaan, bentuk penghargaan, dan acara seremonial yang dilakukan tidak mengandung unsur yang bertentangan dengan aqidah, syariah, dan akhlak mulia, seperti syirik, kultus, maksiat, dan lain-lain.

KK Indonesia membuka pintu lebar bagi siapa saja yang ingin bergabung baik hanya menjadi member maupun dan distributor dari MLM KK Indonesia. Di sisi lain, berkaitan dengan pelatihan yang diberikan kepada member atau anggotanya, KK Indonesia selalu berupaya untuk melakukan secara berkesinambungan. Adapun pelatihan yang diberikan bermacam jenisnya. Menurut Prof. Dr. H. A. Faisol Haq, M.Ag, kegiatan pembinaan yang dilakukan Multi Level Marketing (MLM) atau perusahaan manapun harus bukan merupakan sesuatu yang diharamkan atau ditentang dalam Islam. Pelatihan yang dilakukan juga untuk menambah pengetahuan distributor mengenai pemasaran. Termasuk juga penghargaan kepada distributor yang telah memiliki cukup point dan ditukarkan dengan kegiatan kerohanian contohnya umroh, hal tersebut merupakan Hal yang wajar didapat oleh distributor dan tidak melarang kaidah Islam. Karena, distributor mengumpulkan point hingga cukup untuk ditukarkan dengan umroh berdasarkan hasil usaha yang dilakukan distributor. Dengan demikian point ke-10 (sepuluh) seperti yang disyaratkan dalam fatwa Majelis Ulama Indonesia telah terpenuhi.

11. Setiap mitra usaha yang melakukan perekrutan keanggotaan berkewajiban melakukan pembinaan dan pengawasan kepada anggota yang direkrutnya tersebut.

KK mewajibkan setiap distributor yang telah melakukan kegiatan sponsoring distributor-distributor baru, harus membina para distributornya secara benar. Sehingga target-target yang ingin dicapai oleh distributor baru dapat terwujud dan tidak akan melakukan penyelewengan kewajiban distributor. Tidak hanya para distributor saja yang melakukan 
pembinaan, KK Indonesia juga melakukan kegiatan yang biasanya dalam bentuk seminar yang terkadang disertai dengan kegiatan outbond untuk melatih soft skill. Dengan demikian point ke-11 (sepuluh) seperti yang disyaratkan dalam fatwa Majelis Ulama Indonesia telah terpenuhi.

12. Tidak melakukan kegiatan money game.

KK Indonesia sebagai perusahaan Multi Level Marketing yang telah terdftar dalam APLI atau Asosiasi Penjualan Langsung Indonesia. Dengan demikian, KK Indonesia tidak melakukan kegiatan money game yang ditandai kepemilikan sertifikat tersebut. Kepemilikan sertifikat APLI mensyaratkan bahwa tidak melakukan money game. Sehingga poin ke-12 (dua belas) telah terpenuhi.

\section{KESIMPULAN DAN SARAN}

\section{A. Simpulan}

Simpulan yang dapat ditarik berdasarkan hasil penelitian yang dikaitkan dengan 12 poin persyaratan MLM yang sesuai dengan Fatwa DSN MUI nomor 75/DSN/MUI/VII/2009 pada tanggal 25 Juli 2009 di Jakarta, adalah Multi Level Marketing (MLM) KK Indonesia hanya memenuhi 11 (sebelas) dari poin indikator Fatwa DSN MUI. Hal tersbut dikarenakan KK Indonesia masih melakukan excessive mark up.

\section{DAFTAR PUSTAKA}

Haryanti, Eva. 2012. Dasar-dasar Bisnis, (Online), (http://evahariyantifst.web.u nair.ac.id/artikel_detail41332-

Konsep\%20Sistem\%20Informasi-

Dasar Dasar\%20Bisnis.html, diaks es pada tanggal 17 September 2013)

KK Indonesia. 2009. Visi Misi dan Rencana Pemasaran KK Indonesia. Jakarta: KK Indonesia

Kiyosaki, Robert T. 2012. Rich Dad's Guide to Investing: Model Investasi Orang Terkaya. Jakarta: PT. Gramedia

Purnomo, R. Serfianto D. dkk. 2011. Multi Level Marketing Money Game \& Skema Piramid. Jakarta: PT. Elex Media Komputindo

Santoso, Benny. 2006. All About MLM: Memahami Lebih Jauh MLM dan Pernak-perniknya. Yogyakarta: Andi Publisher.

Sugiyono. 2012. Metode Penelitian Kuantitatif Kualitatif Dan R\&D. Bandung: Alfabeta

Suhendi, Hendi. 2010. Fiqh Muamalah. Jakarta: PT. RajaGrafindo Persada

wikipedia.com

Yin, Robert K. 2012. Studi Kasus Desain \& $\begin{array}{lrr}\text { Metode. Jakarta: } & \text { PT. } \\ \text { RajaGrafindo } & & \text { Persada }\end{array}$ 